\title{
A Pacemaker Current in Dye-Coupled Hilar Interneurons Contributes to the Generation of Giant GABAergic Potentials in Developing Hippocampus
}

\author{
Fabrizio Strata, ${ }^{1}$ Marco Atzori, ${ }^{1}$ Margherita Molnar, ${ }^{1}$ Gabriele Ugolini, ${ }^{1}$ Filippo Tempia, ${ }^{2}$ and \\ Enrico Cherubini ${ }^{1}$ \\ ${ }^{1}$ Biophysics Laboratory, International School for Advanced Studies (SISSA), 34014 Trieste, Italy, and 2Department of \\ Neuroscience, University of Torino, 10125 Torino, Italy
}

\begin{abstract}
The establishment of synaptic connections and their refinement during development require neural activity. Increasing evidence suggests that spontaneous bursts of neural activity within an immature network are mediated by $\gamma$-aminobutyric acid via a paradoxical excitatory action. Our data show that in the developing hippocampus such synchronous burst activity is generated in the hilar region by transiently coupled cells. These cells have been identified as neuronal elements because they fire action potentials and they are not positive for the glial fibrillary
\end{abstract}

acidic protein staining. Oscillations in hilar cells are "paced" by a hyperpolarization-activated current, with properties of $I_{\mathrm{h}}$. Coactivated interneurons synchronously release GABA, which via its excitatory action may serve a neurotrophic function during the refinement of hippocampal circuitry.

Key words: GABA; giant GABAergic potentials; bursting activity; development; hippocampus; pacemaker; inward rectifier current
Highly correlated, spontaneous burst activity is one of the most intriguing electrophysiological features observed during the period of synapse formation (Spear et al., 1972; Rapisardi et al., 1975; Galli and Maffei, 1988; Ben Ari et al., 1989; Meister et al., 1991; MacLeod et al., 1994; Xie et al., 1994). Insights into its developmental role have come from studies of the mammalian visual system. Pairs or multiunit recordings obtained from retinae of embryonic rats or newborn ferrets have shown that the firing of neighboring retinal ganglion cells is strongly correlated (Maffei and Galli-Resta, 1990; Wong et al., 1993). Correlated activity has been suggested as a way to consolidate synaptic connections with target cells (Hebb, 1949). In the developing retina, synchronized discharges are mediated by GABA (Fischer et al., 1995) and require cholinergic inputs (Feller et al., 1996). Like in the retina, synchronous giant GABAergic events can be observed in the LGN of neonatal mice (MacLeod et al., 1994) and in the hippocampus of newborn rats (Ben Ari et al., 1989) (for review, see Cherubini et al., 1991; Xie et al., 1994).

Increasing evidence indicates that GABA, the main inhibitory neurotransmitter in the adult mammalian $\mathrm{CNS}$, during the period of synapse formation excites and depolarizes neurons by an outward flux of $\mathrm{Cl}^{-}$. This effect is bicuculline-sensitive and therefore

Received June 27, 1996; revised Nov. 14, 1996; accepted Nov. 22, 1996.

This work was supported by Consiglio Nazionale delle Ricerche Grant 95.01664.CT04, Human Capital and Mobility Program from the European Union, Instituto Nazionale Fisica della Materia, Human Frontier Science Program (93/93B), and a Sigma Tau Foundation Fellowship (F.S.). We are very grateful to Dr. Ferdinando Rossi for helpful discussions, for advice during the course of the experiments, and for critical reading of this manuscript. We also thank Drs. Mathew Diamond, Mriganka Sur, and Alessandro Treves for critical discussion during manuscript preparation. We thank Lorida Tieri for English revision.

Correspondence should be addressed to Dr. Fabrizio Strata at his present address: Department of Neuroscience, University of Torino, Corso Raffaello 30, I-10125 Torino, Italy

Dr. Atzori's present address: Department of Anatomy and Neurobiology, Wittenberg Building, University of Tennessee Memphis, 855 Monroe Avenue, Memphis, TN 38163.

Copyright (C) 1997 Society for Neuroscience $\quad 0270-6474 / 97 / 171435-12 \$ 05.00 / 0$ is mediated via $\mathrm{GABA}_{\mathrm{A}}$ receptors. A transient excitatory role for GABA can be observed during the development of many neuronal populations (Cherubini et al., 1991; Sakatani et al., 1992; Horváth et al., 1993; Hales et al., 1994; Boyce et al., 1995; Obrietan and van den Pol, 1995; Serafini et al., 1995), and therefore it might represent a general property of the developing brain.

The development of hippocampal circuitry, which starts during prenatal life, is achieved mainly postnatally. The first two postnatal weeks are characterized by granule cell (GC) proliferation, migration into their final positions (Altman and Bayer, 1990), and development of their axons, the mossy fibers (Gaarskjaer, 1986). In this scenario, the scarcity of excitatory input is concomitant with a delayed maturation of GABA-mediated inhibition (Hosokawa et al., 1994). Thus, during the first postnatal week, spontaneously active GABAergic networks provide the main excitatory input to the immature hippocampal neurons, generating $\mathrm{GABA}_{\mathrm{A}}$-mediated oscillatory events, named giant GABAergic potentials (GGPs), driven by ionotropic and metabotropic glutamate receptors (Cherubini et al., 1991; Gaiarsa et al., 1991; Strata et al., 1995b).

In the present report we have addressed the following questions: (1) Where and by what mechanism are synchronous GGPs generated? (2) Where and how are they propagated throughout the developing hippocampus? Our results demonstrate that GGPs are generated in the hilus by a population of electrically coupled neurons. The activity of the network is regulated by an inwardly rectifying cationic conductance, the function of which is to reset the membrane potential to the level of spontaneous firing.

Part of this work has been presented in abstract form (Strata et al., 1995a).

\section{MATERIALS AND METHODS}

Intracellular recordings. Hippocampal slices were obtained from P2-P9 (P0 taken as the day of birth) Wistar rats. Rats were decapitated under urethane anesthesia $(2 \mathrm{gm} / \mathrm{kg}$, i.p.). The brains were removed quickly and 
immersed in oxygenated $\left(95 \% \mathrm{O}_{2} / 5 \% \mathrm{CO}_{2}\right)$ artificial cerebrospinal fluid (ACSF) of the following composition (in $\mathrm{mM}$ ): $\mathrm{NaCl} \mathrm{126,} \mathrm{KCl} \mathrm{3.5}$, $\mathrm{NaH}_{2} \mathrm{PO}_{4} \cdot \mathrm{H}_{2} \mathrm{O} 1.2, \mathrm{MgCl}_{2} \cdot 6 \mathrm{H}_{2} \mathrm{O} 1.3, \mathrm{CaCl}_{2} \cdot 2 \mathrm{H}_{2} \mathrm{O} 2, \mathrm{NaHCO}_{3} 25$, and glucose $11(\mathrm{pH}$ of 7.3-7.4 was obtained by equilibrating the ACSF with $95 \% \quad \mathrm{O}_{2} / 5 \% \mathrm{CO}_{2}$ ). The hippocampi were dissected free, and $600-\mu \mathrm{m}-$ thick slices were cut with a McIlwain tissue chopper and placed at room temperature $\left(20-22^{\circ} \mathrm{C}\right)$ in ACSF. After at least $1 \mathrm{hr}$, an individual slice was placed in the recording chamber, where it was superfused continuously at $36-37^{\circ} \mathrm{C}$ with oxygenated ACSF at a rate of $3-4 \mathrm{ml} / \mathrm{min}$.

Intracellular recordings were performed with microelectrodes filled with $3 \mathrm{M} \mathrm{KCl}$ (resistance $70-120 \mathrm{M} \Omega$ ) and $2 \mathrm{M} \mathrm{K}$-methylsulfate (resistance 100-120 M $\Omega$ ). Current was injected through the recording electrode by means of an Axoclamp-2B amplifier (Axon Instruments, Foster City, CA). Bridge balance was checked repeatedly during the experiments, and capacitive transients were minimized by negative capacity compensation. Recordings were digitized and displayed on an oscilloscope and recorded on a chart recorder. Membrane potential was estimated from the potential observed on withdrawal of the electrode from the cell. Membrane input resistance was measured from the amplitude of small hyperpolarizations ( $200 \mathrm{msec}$ duration) evoked by passing current pulses across the cell membrane. All cells analyzed had a resting membrane potential ranging from $-58 \mathrm{mV}$ to $-74 \mathrm{mV}$, resting input resistance ranging from $35 \mathrm{M} \Omega$ to $120 \mathrm{M} \Omega$, and action potential $>55 \mathrm{mV}$. Pairs of recordings were recorded on a videotape and then analyzed off-line with the program N05 kindly supplied by Dr. S. Traynelis (Emory University, Atlanta, GA). Unless otherwise specified, data are expressed as mean $\pm \mathrm{SD}$.

Drugs were dissolved in ACSF and applied via a three-way tap system. The delay between turning the tap and the first arrival of the solution at the tissue of the changed solution was 25-30 sec. Bath volume exchange was complete within $1 \mathrm{~min}$. Drugs used were bicuculline methiodide, tetrodotoxin (TTX), kynurenic acid, $\mathrm{CsCl}$, and 16-DOXYL stearic acid purchased from Sigma (Indianapolis, IN); octanol and halothane were purchased from Fluka Chemika (Neu-Ulm, Germany). Stock solution of octanol and 16-DOXYL stearic acid were prepared in ethyl alcohol absolute (Carlo Erba reagents) at a concentration of $1 \mathrm{~m}$ and $10 \mathrm{~mm}$ and used at final concentrations of $0.5 \mathrm{~mm}$ and $50 \mu \mathrm{M}$, respectively (dilution 1:2000 for both drugs). Ethyl alcohol absolute had no effects when applied at the same concentration $(n=3)$.

Patch-clamp experiments. Slices were obtained by following the method described by Edwards et al. (1989). Wistar rats, P2-P9, were anesthetized with urethane $(2 \mathrm{gm} / \mathrm{kg}$, i.p.) and then decapitated. The brain was placed in oxygenated Krebs solution. Transverse hippocampal slices, 220-300 $\mu \mathrm{m}$ thick, were cut with a vibroslicer (Vibrocut 3, FTB, Frankfurt, Germany) in a refrigerated solution. They were allowed to recover for at least $1 \mathrm{hr}$ at $32^{\circ} \mathrm{C}$ and then moved to the recording chamber where they were superfused at a constant rate of $3 \mathrm{ml} / \mathrm{min}$ at room temperature $\left(20-26^{\circ} \mathrm{C}\right)$. Hilar interneurons and CA3 or CA1 pyramidal cells were selected under visual control with an Axioscope Zeiss microscope with Nomarski optics and a water immersion lens (400× total magnification). Patch electrodes of 3-4 M $\Omega$ resistance were pulled from borosilicate tubing ( $2 \mathrm{~mm}$ outer diameter). The pipette solution was composed of (in mM): KCl 126, $\mathrm{Na}_{2}$ ATP 1.5 , HEPES $10, \mathrm{MgCl}_{2} 2$, and EGTA 1 . pH was adjusted to 7.35 with $\mathrm{KOH}$. Voltage- and current-clamp experiments were performed with an EPC-7 amplifier (List Medical Instruments, Germany) driven by pClamp 6.0.2 system (Axon Instruments). Recordings with series resistance higher than $30 \mathrm{M} \Omega$ were discarded. Voltageclamp holding potential was -50 or $-40 \mathrm{mV}$. Current signals filtered at $10 \mathrm{kHz}$ were recorded on a videotape. Stored data were filtered at a cutoff frequency of $1-3 \mathrm{kHz}$. Drugs were bath-applied via oxygenated superfusate (see also Intracellular Recordings). Results are reported as mean \pm SD. Comparisons between different groups were done by means of paired Student's $t$ test.

Intracellular injection. Microelectrodes and patch pipettes were filled with a solution containing 3-4\% biocytin (Ne-biotinyl-L-lysine, Sigma). Then biocytin was injected by passing $0.8-1 \mathrm{nA}$ hyperpolarizing and depolarizing pulses alternatively $(200-300 \mathrm{msec}, 0.1 \mathrm{~Hz})$ for at least 10 min. Slices were fixed in $4 \%$ paraformaldehyde in $0.1 \mathrm{M}$ phosphate buffer (PB) for $6 \mathrm{hr}$. Two techniques were used to visualize cells filled with biocytin. After the fixation, slices were washed in Tris buffer $0.1 \mathrm{M}, \mathrm{pH}$ $7.2-7.4$, for at least $30 \mathrm{~min}(3 \times 10 \mathrm{~min})$. Then slices were incubated in an avidin-biotin-peroxidase mixture (Vectastain ABC Kit PK-4000, Vector Laboratories, Burlingame, CA) with $0.5 \%$ Triton X-100 for 2 hr. Slices were washed in PB $0.1 \mathrm{M}$ and then preincubated in acetate buffer $0.1 \mathrm{M}$ and incubated in $0.05 \% 3,3^{\prime}$-diaminobenzidine tetrahydrochloride (DAB,
Sigma) in $0.1 \mathrm{M}$ acetate buffer containing $2.5 \%$ nickel ammonium sulfate to intensify the staining. The solution also contained $\beta$-D-glucose $0.2 \%$, ammonium chloride $0.04 \%$, and glycose oxidase (Sigma). Reaction was interrupted in acetate buffer $0.1 \mathrm{M}$, and slices were mounted on gelatinized $(2 \%)$ slides, dehydrated, and coverslipped. Alternatively, after fixation slices were washed $(4 \times 15 \mathrm{~min})$ in FITC buffer $(150 \mathrm{mM} \mathrm{NaCl}$ and $10 \mathrm{~mm}$ HEPES, $\mathrm{pH}$ 7.4) and then incubated with fluorescinated avidin (Vector) diluted (1:500) in FITC buffer for $1 \mathrm{hr}$. Then slices were placed on gelatinized slides, briefly air-dried, and mounted in Vectashield mounting medium for fluorescence (H-1000, Vector).

Double staining. After fixation slices were washed in $0.1 \mathrm{M} \mathrm{PB}$ and pretreated for $1 \mathrm{hr}$ at room temperature in Blocking Solution $(10 \%$ normal goat serum in $0.1 \mathrm{M}$ PB containing $0.3 \%$ Triton X-100), washed four times (10 min each wash) in $0.1 \mathrm{M} \mathrm{PB}$, and then incubated overnight at $4^{\circ} \mathrm{C}$ with a mouse monoclonal antibody against glial fibrillary acidic protein (GFAP; N358, Amersham, Arlington Heights, IL) diluted 1:100 in Blocking Solution (Vector). The next day, slices were washed in $0.1 \mathrm{M}$ $\mathrm{PB}(4 \times 10 \mathrm{~min})$ and incubated in TRITC-conjugated rabbit anti-mouse immunoglobulins (DAKO, R0270, Glostrup, Denmark) diluted 1:40 in $0.1 \mathrm{M}$ PB for $3 \mathrm{hr}$ at room temperature. After washing $(3 \times 5 \mathrm{~min}$, in 0.1 $\mathrm{M} P B)$, slices then were washed in FITC buffer and finally incubated with fluorescinated avidin (Vector) diluted 1:500 in FITC buffer for $1 \mathrm{hr}$ (as described above).

Finally, frozen tissue was sliced further, $50 \mu \mathrm{m}$ thick, on a sliding microtome; this was done after cryoprotection with $30 \%$ sucrose in 0.1 м PB.

\section{RESULTS}

\section{Paired intracellular recordings reveal correlated bursts}

To localize the origin of GGPs, we performed 18 paired intracellular recordings, lasting from $15 \mathrm{~min}$ to several hours, from hilar-CA3 $(n=3)$, hilar-CA1 $(n=3)$, CA3-CA3 $(n=5)$, and CA3-CA1 $(n=7)$ neurons. All pairs exhibited spontaneous GGPs, except in three CA3-CA1 pairs in which GGPs were observed only in the CA3 region. These consisted of large depolarizations with superimposed fast action potentials (see inset, Fig. 1). Their frequency was inversely related to age, ranging between $0.13 \mathrm{~Hz}$ at $\mathrm{P} 4$ and $0.01 \mathrm{~Hz}$ at $\mathrm{P} 7$.

Figure $1 A$ illustrates GGPs recorded simultaneously from a hilar interneuron and a CA3 pyramidal neuron and from two pyramidal neurons of the CA3 and CA1 regions. Crosscorrelation histograms were constructed from the two paired recordings of Figure $1 A$ to evaluate quantitatively the time difference between the onset of each GGP recorded in one neuron and the closest event in the other (Fig. $1 B$ ). The top histogram (hilus taken as the reference) has a narrow peak centered on zero, constituted by $20 \%$ of events, and a wider component, scattered within $15 \mathrm{msec}$, constituted by $51 \%$ of the events (mean latency $7.5 \pm 3.9 \mathrm{msec})$. In the abscissa, all the counts to the left of the zero represent the cases in which the GGP in the second cell (CA3 pyramidal neuron) preceded the GGP in the first one (hilar interneuron). The mean latency between the onset of GGPs in the hilar and CA3 region, obtained from three pairs of recording, was $26.4 \pm 18.2 \mathrm{msec}$. In contrast to the top plot, in the bottom histogram (CA3 taken as the reference), the distribution of events was more scattered $(45.5 \%$ of the events occurred with a delay of $40-60 \mathrm{msec}$ ). The mean latency between the onset of GGPs in the CA3 and CA1 regions, obtained from four of seven pairs, was $48.9 \pm 4.3 \mathrm{msec}$, suggesting that GGPs occurred first in the CA3 region. Moreover, in the case of hilar-CA1 pair recordings, the mean time difference was $87.4 \pm 32.4 \mathrm{msec}(n=3)$. Finally, when two CA3 pyramidal cells were impaled simultaneously, giant events recorded by the electrode closer to the hilar region preceded those recorded by the other electrode. The delay between the onset of the two events was a function of the distance between the two impaled cells, ranging from a minimum of $5 \mathrm{msec}$ when 
11
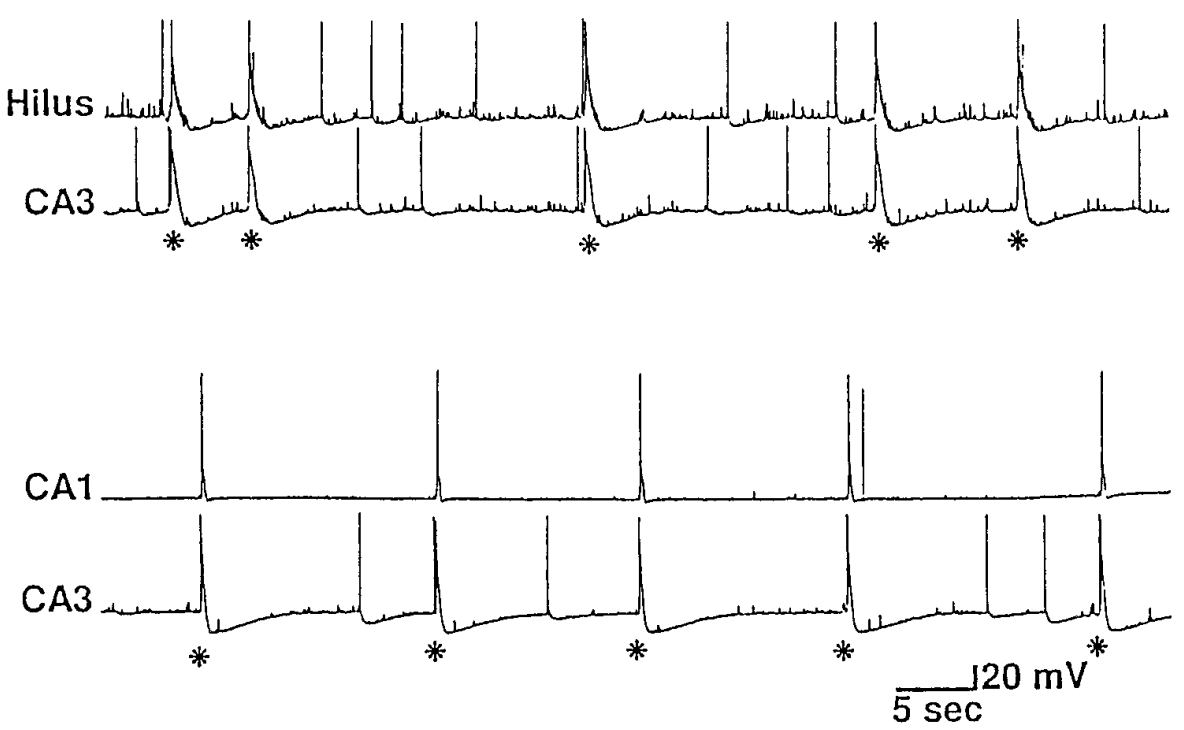

B
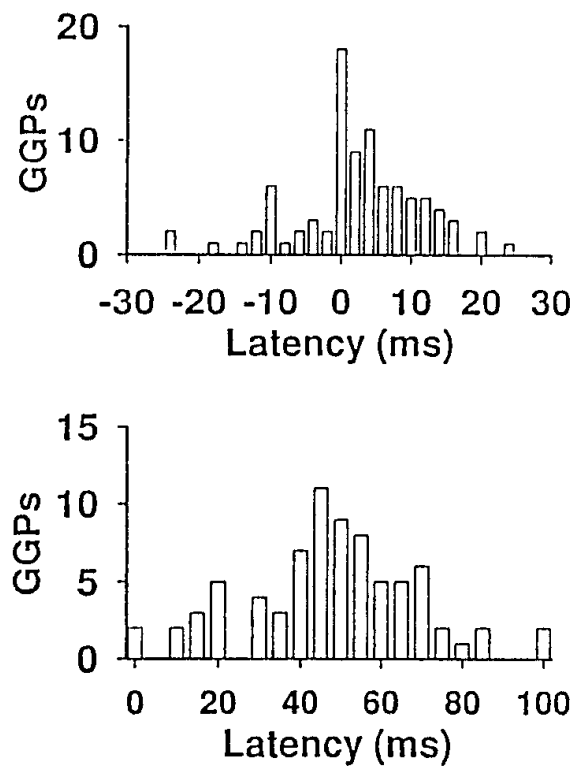

Figure 1. Correlation between GGPs occurring in different hippocampal subfields. $A$, Pair of recordings obtained at $\mathrm{P} 4$ from a hilar interneuron and a CA3 pyramidal neuron and from two pyramidal neurons of the CA3 and CA1 subfields. A single GGP is shown in the inset above the traces and marked by an asterisk in the traces. $B$, Cross-correlation histograms obtained from pairs of recordings shown in $A$. The top histogram (hilus taken as reference) has a narrow peak centered at zero (20\% of the events) and a broader distribution grouped within $15 \mathrm{msec}(51 \%$ of the events). Number of events, 90 ; bin width, 2 msec. In the bottom histogram GGPs in CA1 are plotted as a function of the time after the event recorded from CA3. Number of events, 77 ; bin width, 5 msec.

the distance was shorter than $0.5 \mathrm{~mm}$ to a maximum of $24 \mathrm{msec}$ when it was $\sim 2 \mathrm{~mm}$. On average it was $14.4 \pm 8.3 \mathrm{msec}(n=4)$. A schematic overview is given in Figure $2 \mathrm{~A}$.

To assess further the contribution of hilar neurons to the generation of GGPs, we made recordings from CA3 and CA1 hippocampal regions before and after their isolation by a knife cut from the hilus (a scheme of the experimental condition is shown in Fig. 2B). After the isolation from the hilus, GGPs were detected neither in CA3 $(n=4)$ nor in CA1 $(n=2)$, although they were detected in both regions before the cut. However, GGPs still could be recorded in the hilus $(n=2)$. Moreover, when the CA1 subfield only was removed $(n=2)$, GGPs were still present in the $\mathrm{CA} 3$ region.

\section{GGPs in the hilus and in the CA1 region are GABA $_{A}$-mediated}

In six experiments we have investigated the ionic mechanisms underlying the generation of giant depolarizing events detected in the hilus. As shown in Figure $3 A$, GGPs recorded with $\mathrm{KCl}$ containing microelectrodes reversed polarity at $-4 \mathrm{mV}$. On average the reversal obtained from three cells was $-11 \pm 6.3 \mathrm{mV}$. In the presence of TTX $(1 \mu \mathrm{M})$, application of GABA (on the same cell, Fig. $3 B$ ) elicited at $-52 \mathrm{mV}$ a membrane depolarization that reversed at $-7 \mathrm{mV}$ a value very close to that obtained for GGPs. On average the reversal of GABA responses was $-15 \pm 7.6 \mathrm{mV}$ $(n=3)$. Therefore, we can conclude that both GGPs and GABA shared the same ionic mechanisms. Moreover, when microelectrodes were filled with K-methylsulfate $(n=2)$, smaller amplitude events were detected in the same region. They changed polarity at -37 and $-42 \mathrm{mV}$, respectively, indicating that GGPs were dependent on $\left[\mathrm{Cl}^{-}\right]_{\mathrm{i}}$ (data not shown). GGPs were reversibly blocked by the selective $\mathrm{GABA}_{\mathrm{A}}$ antagonist bicuculline $(10 \mu \mathrm{M}$; $n=7$; Fig. $3 C$ ), implying that they were GABA $_{\mathrm{A}}$-mediated. As in the $\mathrm{CA} 3$ and in the hilus, also in the CA1 region GGPs were $\mathrm{GABA}_{\mathrm{A}}$-mediated, because they reversed polarity at -17 and $-22 \mathrm{mV}$ (at P3 and P4, respectively, with $\mathrm{KCl}$-filled microelectrodes) and were reversibly blocked by bicuculline $(n=2$; data not shown). Moreover, as in the CA3, in the hilus, and in the CA1 region, GGPs were blocked by kynurenic acid ( $1 \mathrm{~mm}, n=5)$, indicating that glutamate acting on ionotropic receptors represents the common drive for GGPs over the entire hippocampus.

\section{Cells in the hilar region are electrically coupled}

Biocytin was injected in 57 neurons located in the hilus, CA3, and CA1 regions, from $\mathrm{P} 1$ to $\mathrm{P} 7$, and in 19 neurons in the same region during the second week of postnatal life. Unexpectedly, we found that, when the injection was made in hilar interneurons, many additional surrounding cells also were labeled (Fig. 4A,B). Biocytin also was injected through low-resistance patch-clamp pipettes $(n=52)$. By injecting the hilar neurons of rats younger than P7, in $68 \%$ of the cases we could label from 3 to 20 neurons. A complex network of axonal branches could be observed extending mainly from the hilus to CA 3 and also to CA1 and to the alveus. In three cases neuronal processes extending to the CA1 region and the subiculum, after having crossed the stratum lacunosummolecolare, could be observed (data not shown). In contrast, when 
A
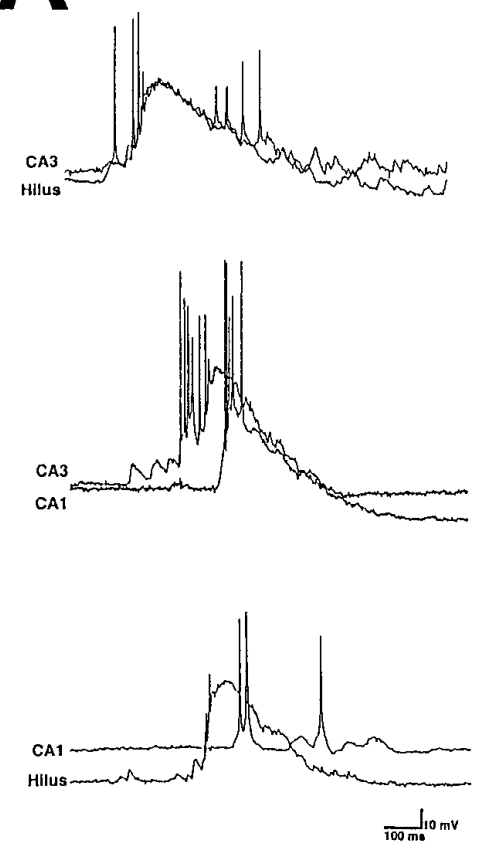

B

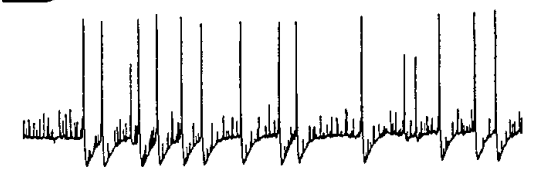

CA3 (before cut)

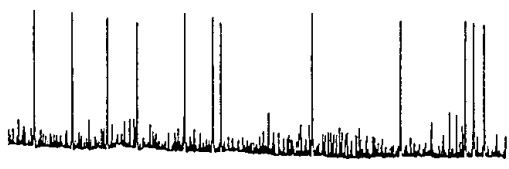

CA1 (before cut)

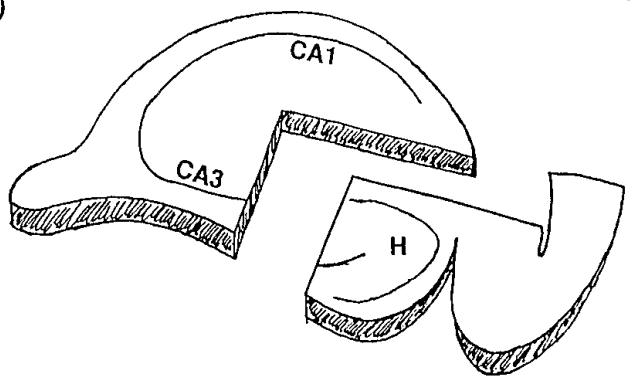

CA3 after knife cut

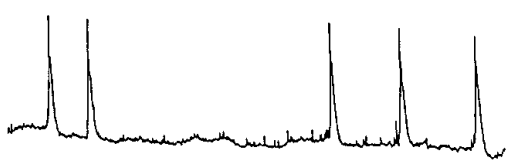

Figure 2. Giant GABAergic potentials were detected in the isolated hilus. A, Pairs of GGPs recorded from different hippocampal fields are superimposed. It can be observed that GGPs recorded in the hilus and CA3 region are almost synchronous, whereas those detected in the CA3-CA1 or hilus-CA1 occur with a latency of several milliseconds (also see text). $B$, Schematic representation of the experimental condition before and after isolation of the hilus by knife cut. GGPs were detected before the cut either in the CA3 (top left trace) or in the CA1 (top right trace) fields. After the knife cut, GGPs were still detected in the hilus ( $\mathrm{H}$, bottom right trace), whereas they were not detected either in CA3 (bottom left trace) or in CA1 fields (data not shown). Scale bars: $20 \mathrm{mV}$ vertical; $30 \mathrm{sec}$ horizontal, except for the bottom right trace, which is $6 \mathrm{sec}$.

biocytin was injected into CA1 or CA3 pyramidal cells, labeling was restricted to the injected cell (Fig. 4B). Moreover, no dye coupling was observed when a hilar mossy cell was injected with biocytin (Fig. $5 B ; n=6$ ). Finally, growth cones often were visible on processes of hilar interneurons (Fig. $5 C$ ).

\section{Coupled cells are not glial elements}

A previous report has shown that injecting low molecular weight dyes in a single astrocyte reveals a widespread coupling between these cells. The vast majority of dye-coupled astrocytes are GFAP-positive (Konietzko and Müller, 1994). In our case, all of the injected cells in the hilus were identified as neuronal elements, because an action potential could be elicited by a small depolarizing current pulse. To further assure the nonastrocytic nature of the hilar-coupled cells, we used a double-labeling protocol (see also Materials and Methods). As shown in Figure 5A, the dyecoupled hilar neurons and the GFAP-positive cells did not overlap. Therefore, it is likely that the coupled cells in the hilus are neuronal elements. According to Amaral classification (Amaral, 1978), the majority of the coupled cells could be identified as pyramidal-like stellate cells, unalignated pyramidal cells, stellate cells of the dentate gyrus/hilus border with ascending and descending axons, giant aspiny stellate cells, small aspiny stellate cells with web-like axonal plexus, and oviform cells. In one case, also, two coupled long-spined multipolar cells were identified. The pattern of dye coupling observed was not homogeneous: sometimes coupled interneurons were very close, whereas sometimes soma of labeled neurons were distant one from the other, and stained neurons were observed also in the stratum lacunosum-molecolare in CA3, in CA1, and in the alveus. Moreover, in the stratum radiatum of the CA1 subfield, the morphology of four interneurons was disclosed by injecting a single neuron (data not shown).

\section{Coupling between hilar neurons was developmentally regulated}

When biocytin was injected into a hilar neuron during the first postnatal week, the number of neurons labeled varied between 3 and 60 . Thus, at P3, up to 60 neurons were labeled by injecting a single hilar cell. On average $18.7 \pm 9$ (mean \pm SEM) labeled neurons were observed between $\mathrm{P} 1$ and $\mathrm{P} 3$, and $5.7 \pm 0.7$ (mean \pm SEM) between P4 and P7 (Fig. 6). During the second postnatal week a marked decrease in cell coupling was observed (from 1 to 5). On average dye-coupled cells were $1.9 \pm 0.4$ (mean \pm SEM).

\section{An inward rectifier cationic conductance resets hilar neurons}

The next question to be addressed was how this complex network of electrically coupled interneurons was activated. The oscillatory behavior of GGPs led us to hypothesize that a "pacemaker" current, similar to the one present in cells endowed with intrinsic rhythmic properties, like cardiac myocytes (Di Francesco, 1993) or thalamic relay neurons (McCormick and Pape, 1990), could be involved in GGPs generation. To test this hypothesis, we performed experiments on hilar interneurons, patch-clamped under visual control and under conditions that limited the influence of other voltage-dependent currents. Slices were superfused with ACSF containing TTX $(1 \mu \mathrm{M})$, 4-aminopyridine (4-AP, $500 \mu \mathrm{M})$, tetraethylammonium (TEA, $20 \mathrm{~mm})$, nickel $\left(\mathrm{Ni}^{2+}, 50 \mu \mathrm{M}\right)$, and cadmium $\left(\mathrm{Cd}^{2+}, 50 \mu \mathrm{M}\right)$ to block fast sodium and most voltagedependent potassium and calcium currents. Hyperpolarizing volt- 
A

$+8 \mathrm{mV}$

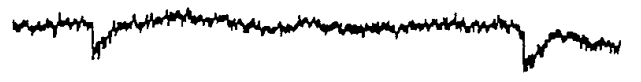

$-20 \mathrm{mV}$

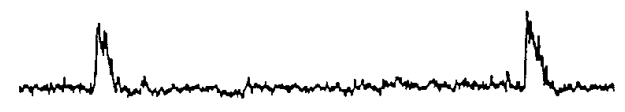

$-44 \mathrm{mV}$

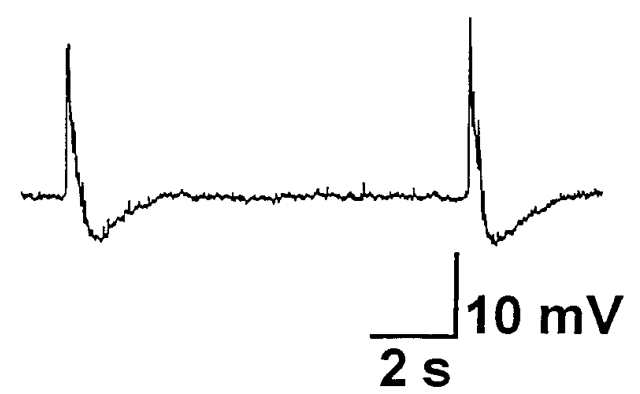

GABA

$+13 \mathrm{mV}$

$-25 \mathrm{mV}$

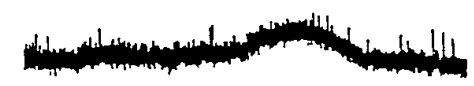

$-52 \mathrm{mV}$

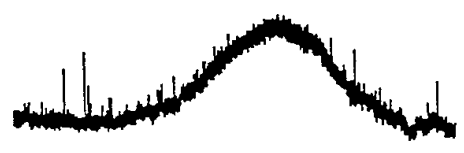

\section{$10 \mathrm{mV}$ \\ $1 \mathrm{~min}$}

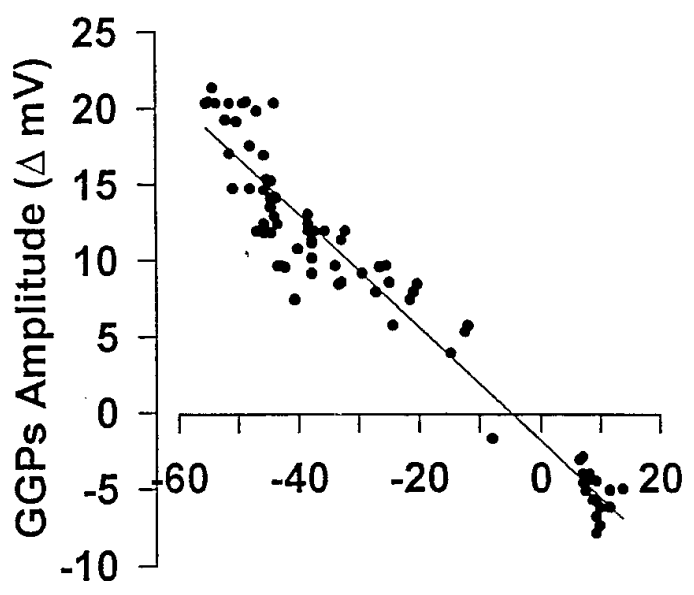

Membrane Potential (mV)

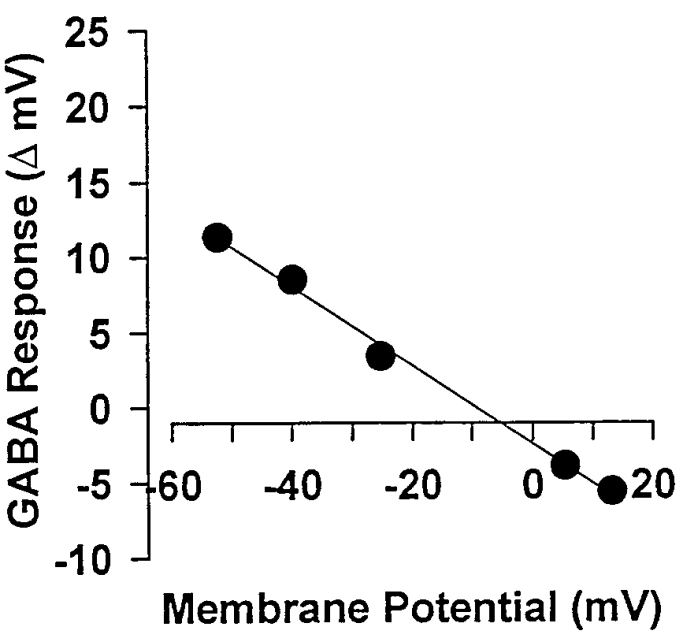

Control

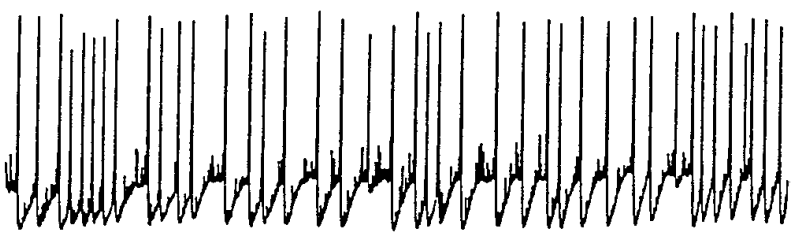

\section{Bicuculline $(10 \mu \mathrm{M})$}

Figure 3. GGPs in the hilus are $\mathrm{GABA}_{\mathrm{A}}$-mediated. $A$, Traces showing spontaneously occurring GGPs (recorded with a KCl-containing microelectrode from a hilar cell at P2) at different membrane potentials. On the right, the amplitude of GGPs is plotted versus the membrane potential. Data points are fit with a regression line. $B$, Responses to exogenously applied GABA $(200 \mu \mathrm{M})$ in the presence of TTX $(1 \mu \mathrm{M})$ at different potentials $($ left $)$, obtained from the same neuron. On the right, the amplitude of the responses is plotted against the membrane potential. As indicated by the regression line, the reversal of GABA responses is very close to that obtained for GGPs. $C$, GGPs are abolished by bicuculline $(10 \mu \mathrm{M})$. 

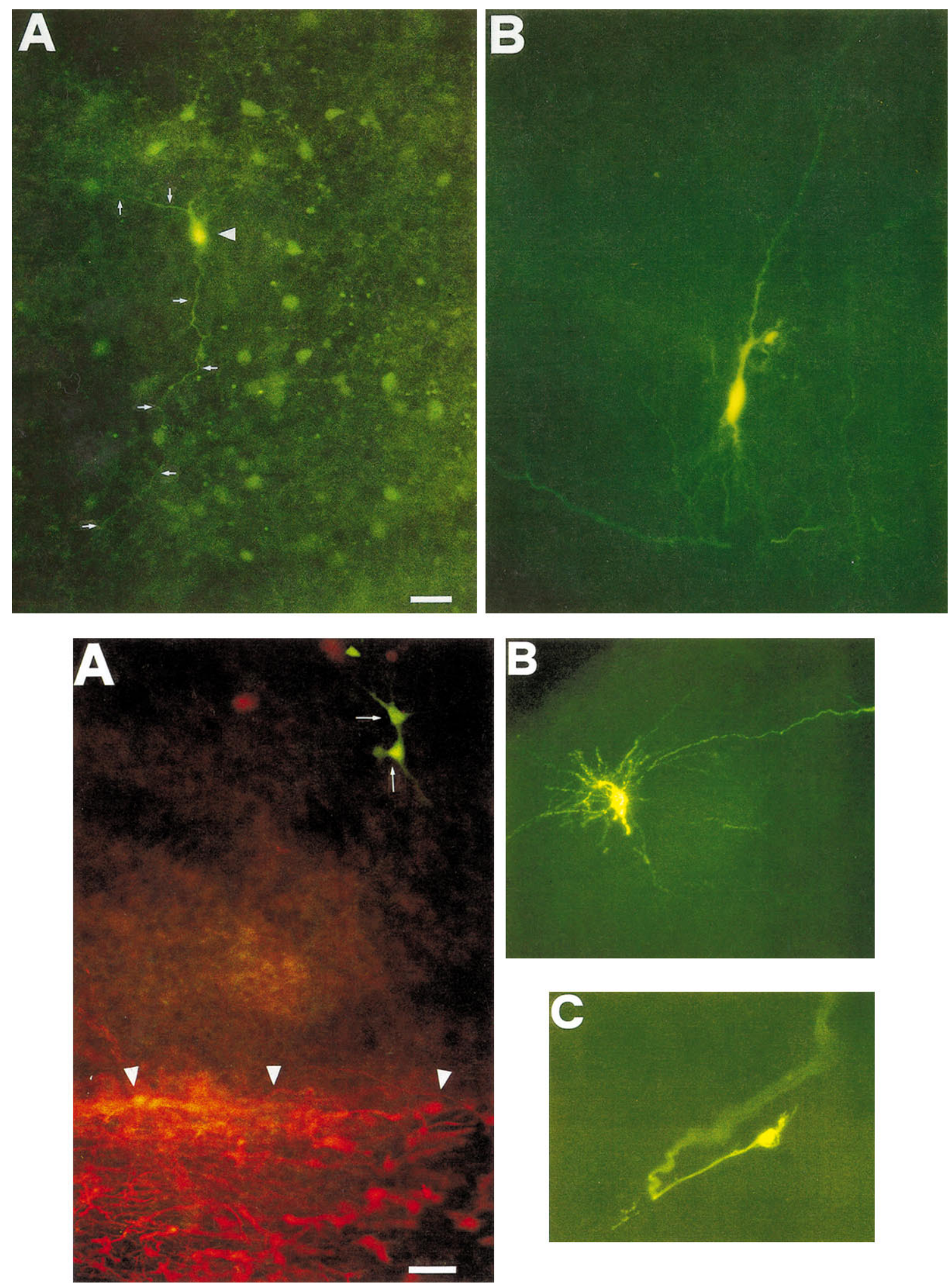

Figure 4. Top. Biocytin-injected hilar interneuron, but not pyramidal cell, reveals surrounding cells. $A$, P3 hilar cells in a $50 \mu \mathrm{m}$ hippocampal slice. The injected interneuron (arrowhead) is coupled to a cluster of surrounding cells. Two neuronal processes (white arrows) connect neighboring cells. $B$, Staining of a single CA3 pyramidal neuron. Scale bar, $44 \mu \mathrm{m}$.

Figure 5. Bottom. Dye-coupled hilar cells are not glial elements. A, Dye-coupled hilar cells (white arrows) are not colocalized to GFAP-positive cells (white arrowheads) in a P2 rat hippocampus. Microphotograph of biocytin-injected neuron is observed with FITC filter combination cubes in a whole-mounted slice $500 \mu \mathrm{m}$ thick. $B$, A P4 single hilar mossy cell. $C$, Growth cone of a P4 hilar interneuron. Scale bar: $A, 60 \mu \mathrm{m} ; B, 50 \mu \mathrm{m} ; C, 10 \mu \mathrm{m}$. 


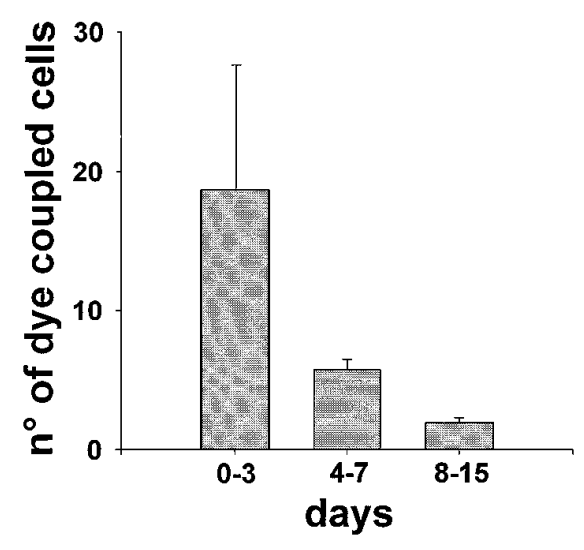

Figure 6. Dye coupling is developmentally regulated. Histogram shows the developmental disappearance of dye coupling. The number of dyecoupled cells was significantly $(p<0.05)$ reduced when biocytin was injected in older animals.

age steps from a holding potential of -50 or $-40 \mathrm{mV}$ revealed a time-dependent inwardly rectifying current $\left(I_{\mathrm{h}}\right)$, the amplitude and rate of activation of which increased at more negative voltages with no sign of inactivation (Fig. $7 A$ ). As shown in Figure $7 B$, the steady-state current-voltage relationship showed that $I_{\mathrm{h}}$ was activated at membrane potentials more negative than $-60 \mathrm{mV}$. The reversal of the tail currents obtained with a double-pulse paradigm was $-50.3 \pm 6.3 \mathrm{mV}(n=3$; data not shown $)$; the deviation of the reversal potential from the value of $-94 \mathrm{mV}$, predicted by the Nernst equation for $\mathrm{K}^{+}$, may reflect some permeability of the channel to $\mathrm{Na}^{+}$.

To determine the activation curve, in 24 experiments we plotted the amplitude of steady-state currents elicited by hyperpolarizing steps to various potentials and normalized it to that obtained at $-120 \mathrm{mV}$, when the current was fully activated, against different voltages. Data points were fit with a two-state Boltzmann distribution of the form $I / I_{\max }=1 /\left[1+\exp \left(V_{\mathrm{h}}-V\right) / k\right]$, in which $I / I_{\max }$ is the normalized current, $V$ is the pulse potential, $V_{\mathrm{h}}$ is the voltage for half-maximal activation, and $k$ is the slope factor. Halfmaximal activation occurred at $-93.5 \pm 1.0 \mathrm{mV}$ (mean $\pm \mathrm{SEM}$; $n=24$; Fig. $7 C$ ). The time course of activation was well fit by a single exponential function and was strongly voltage-dependent (time constants ranged between $1800 \mathrm{msec}$ at $-90 \mathrm{mV}$ and 300 $\mathrm{msec}$ at $-120 \mathrm{mV}$ ). For a hyperpolarizing voltage step of $70 \mathrm{mV}$ from a holding potential of $-50 \mathrm{mV}$, the mean time constant of activation was $336 \pm 19 \mathrm{msec}$. In cardiac and thalamic cells, $I_{\mathrm{h}}$ usually is blocked by high concentrations (in mM range) of extracellular $\mathrm{Cs}^{+}$(McCormick and Pape, 1990; Di Francesco, 1993). The same has been reported recently in the retinal horizontal cells (Dong and Werblin, 1995). In hilar neurons, $I_{\mathrm{h}}$ was very sensitive to external $\mathrm{Cs}^{+}$. Thus, $\mathrm{Cs}^{+}(300 \mu \mathrm{M})$ significantly $(p<0.05$, paired Student's $t$ test) reduced the amplitude of the current by $64 \pm 5 \%(n=4$; Fig. $7 A, B)$.

\section{Could a network of electrically coupled interneurons "beating" in the hilus of developing hippocampus generate GGPs in the CA3 or CA1 region?}

This question was answered by applying octanol, a known gap junction uncoupler (Perez-Velazquez et al., 1994). Octanol (0.5 $\mathrm{mM}$, applied in the bath for $5 \mathrm{~min}$ ) totally abolished GGPs in all slices tested within 3 min ( $n=10$, Fig. 8). In 4 of 10 experiments, octanol caused a membrane depolarization (ranging between 4 and $19 \mathrm{mV}$ ) that outlasted the application of the drug. The effect
A Control

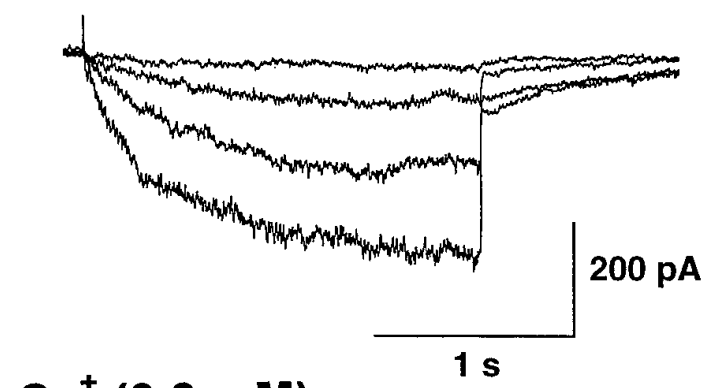

$\mathrm{Cs}^{+}(0.3 \mathrm{mM})$
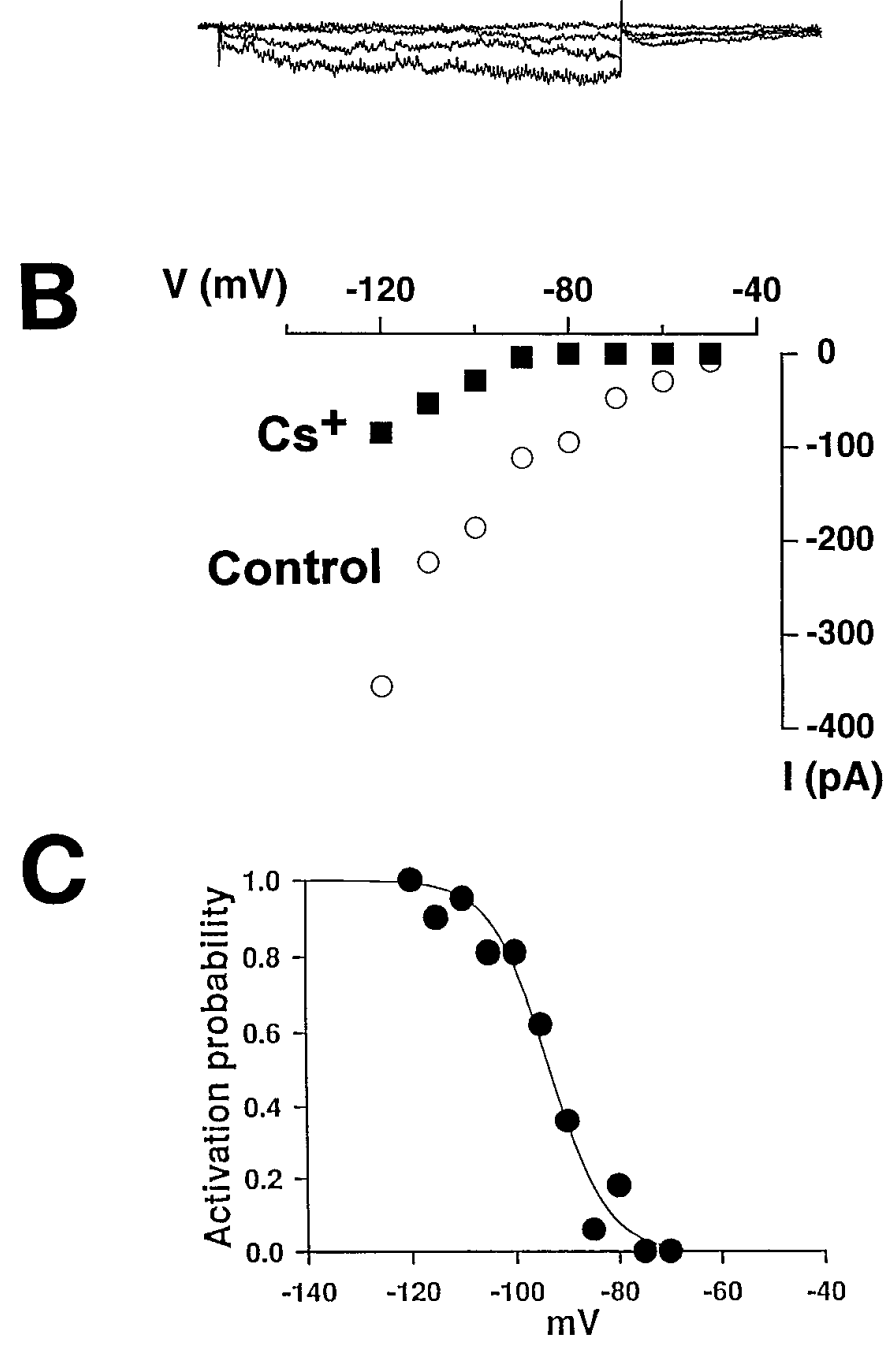

Figure 7. Hilar interneurons bear a pacemaker current. $A$, Traces showing an inward current activated by $20,40,60$, and $80 \mathrm{mV}$ hyperpolarizing voltage steps ( $2 \mathrm{sec}$ duration) from a holding potential of $-40 \mathrm{mV}$ before (above) and during (below) bath application of $\mathrm{Cs}^{+}$(0.3 mM). B, I-V relationship for the cell shown in $A$ before and during application of $\mathrm{Cs}^{+}$. $C$, Steady-state activation curve. Data points were fit by a two-state Boltzmann distribution.

of octanol was reversible, and a full recovery was obtained in $10-15 \mathrm{~min}$. In the majority of the cells (6 of 10), the membrane input resistance, detected by the change of the electrotonic potentials after the injection of a steady hyperpolarizing current through the recording electrode, was not affected by octanol. 
A
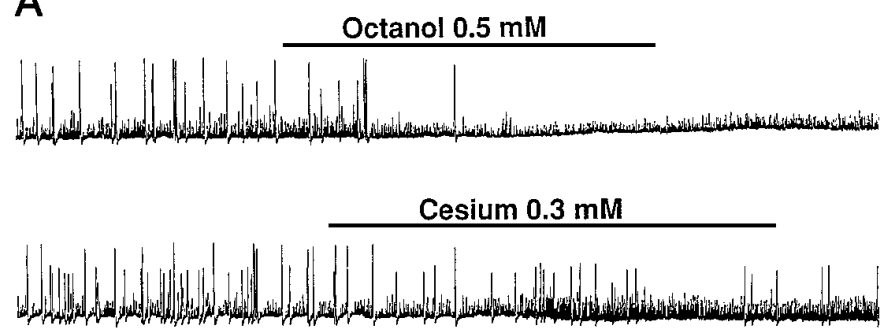

$\underset{1 \mathrm{~min}}{\mathrm{minV}}$

B

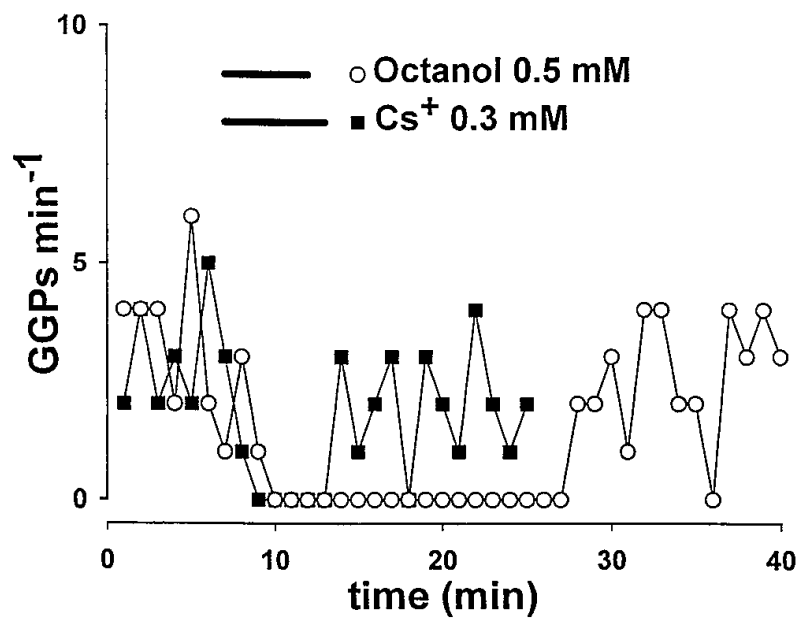

Figure 8. The inward rectifier "paces" GGPs. $A$, Spontaneous GABAergic bursts in a CA3 pyramidal neuron at P3 (top trace) and in a hilar interneuron at $\mathrm{P} 4$ (bottom trace). Resting membrane potentials are -68 $\mathrm{mV}$ in the pyramidal cell and $-59 \mathrm{mV}$ in the hilar interneurons. Octanol slightly depolarized the membrane and reversibly inhibited GGPs. $\mathrm{Cs}^{+}$ blocked GGPs as well. $B$, Time course of the GGPs frequency for the cells shown in $A$ before, during (see bars in inset), and after application of drugs.

Other gap junction blockers such as 16-DOXYL stearic acid (50 $\mu \mathrm{M})$ and halothane (2\%) inhibited GGPs $(n=6$; data not shown) as well. To test whether these drugs really affected electrical coupling between neurons, we injected biocytin in the presence of octanol $(n=3)$ or stearic acid $(n=2)$. The application of these uncouplers to $\mathrm{P} 4-\mathrm{P} 7$ cells reduced cluster size to a mean value of $1.2 \pm 0.45$ (Figs. 9 and 10).

GGPs frequency was reversibly reduced by external $\mathrm{Cs}^{+}(100$ $\mu \mathrm{M}$, from $0.06 \pm 0.02$ to $0.03 \pm 0.008 \mathrm{~Hz}) . \mathrm{Cs}^{+}$, applied at the same concentration used to block $I_{\mathrm{h}}(300 \mu \mathrm{M} ; n=4$; Fig. 8), completely abolished GGPs. The effect was rapid in onset $(\sim 2$ min) and washed out in $2-6 \mathrm{~min}$. $\mathrm{Cs}^{+}$also induced a slight hyperpolarization of the membrane (ranging from 3 to $8 \mathrm{mV}$ ).

\section{DISCUSSION}

The present experiments show that (1) during a restricted period of postnatal life, spontaneous network-driven GABA-mediated giant events can be recorded over the entire hippocampus; (2) they originate from electrically coupled hilar interneurons and propagate first to the CA3 and then to the CA1 subfields; (3) a pacemaker current with properties similar to $I_{\mathrm{h}}$ dictates the frequency of GGPs.

Spontaneous network-driven giant events found in the hilus and in the CA1 subfield were similar in all respects to those already described in the CA3 region (Ben Ari et al., 1989; Xie and Smart,

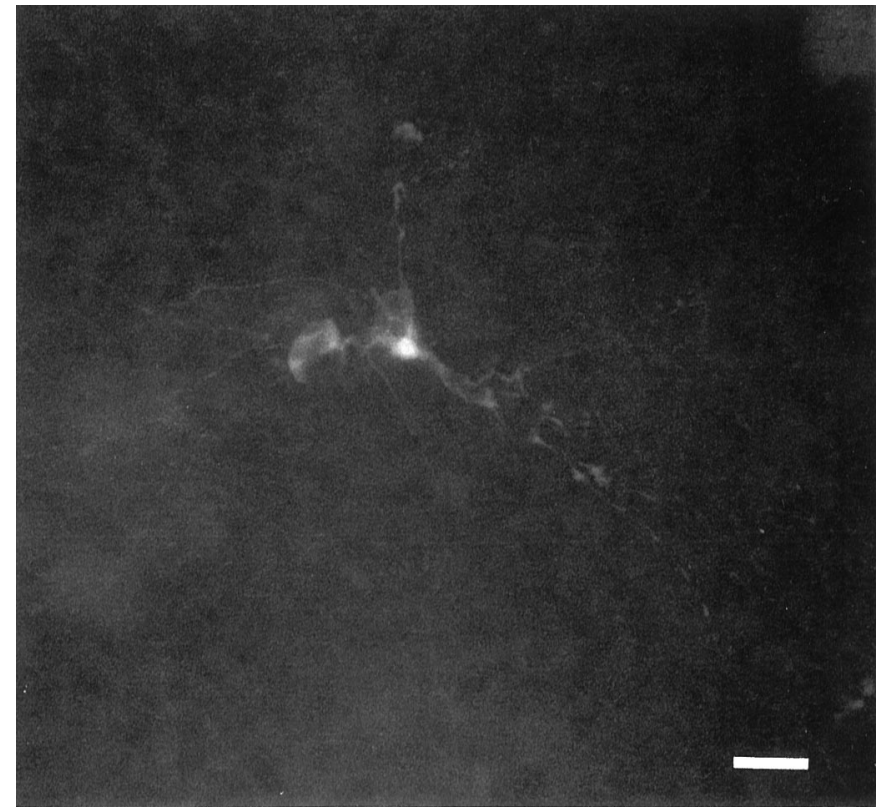

Figure 9. Octanol restricts interneurons cluster size. When biocytin was injected in a P3 hilar cell in the presence of octanol $0.5 \mathrm{~mm}$, only one cell was observed. Scale bar, $60 \mu \mathrm{m}$.

1990). They were mediated by GABA acting on $\mathrm{GABA}_{\mathrm{A}}$ receptors, because in the same cell they reversed at the same potential of exogenously applied GABA and were blocked by the $\mathrm{GABA}_{\mathrm{A}}$ antagonist bicuculline. In pairs of intracellular recordings GGPS seemed to be synchronous. However, cross-correlograms between pairs of cells in different regions showed a different degree of correlation between hilar and CA3 or CA3 and CA1 neurons, respectively. The high degree of correlation found in the former case suggests that GGPs first originate in the hilus and then propagate successively to the CA 3 and CA 1 subfields. In adult brains, hippocampal regions are linked by unique and primarily unidirectional connections. Thus, the input received by the GCs is projected via their mossy fibers to the CA3 field, which in turn provide the major input to the CA1 through the Schaffer collaterals (Andersen et al., 1971). In neonates, the propagation of spontaneous GGPs follows approximately the same pathway taken in the adult by information flow. Because at this early developmental stage the connections between GCs and CA3 pyramidal neurons are still poorly developed (85\% of the adult population of GCs are generated and migrate after birth, Altman and Bayer, 1990), spontaneous GGPs generated in the hilus might offer important clues as to how hippocampal circuitry develops.

The morphological substrate for GGPs generation is represented by electrically coupled hilar interneurons, because clusters of many cells were revealed by injecting biocytin in a single neuron. We believe that this effect was not artifactual because (1) we could not stain any neuron when biocytin was injected extracellularly or on the slice surface; (2) as in the neocortex and in the retina (Peinado et al., 1993; Penn et al., 1994) (for recent review, see Kandler and Katz, 1995), a drop-off in intensity of labeling beyond the injected cell often was seen; (3) when, by chance, a hilar mossy cell was injected with biocytin, no dye coupling was observed; (4) labeled cells often were distant from the injected cell.

Injected cells in the hilus were identified as neurons by their ability to generate action potentials. The lack of colocalization of 


\section{control}

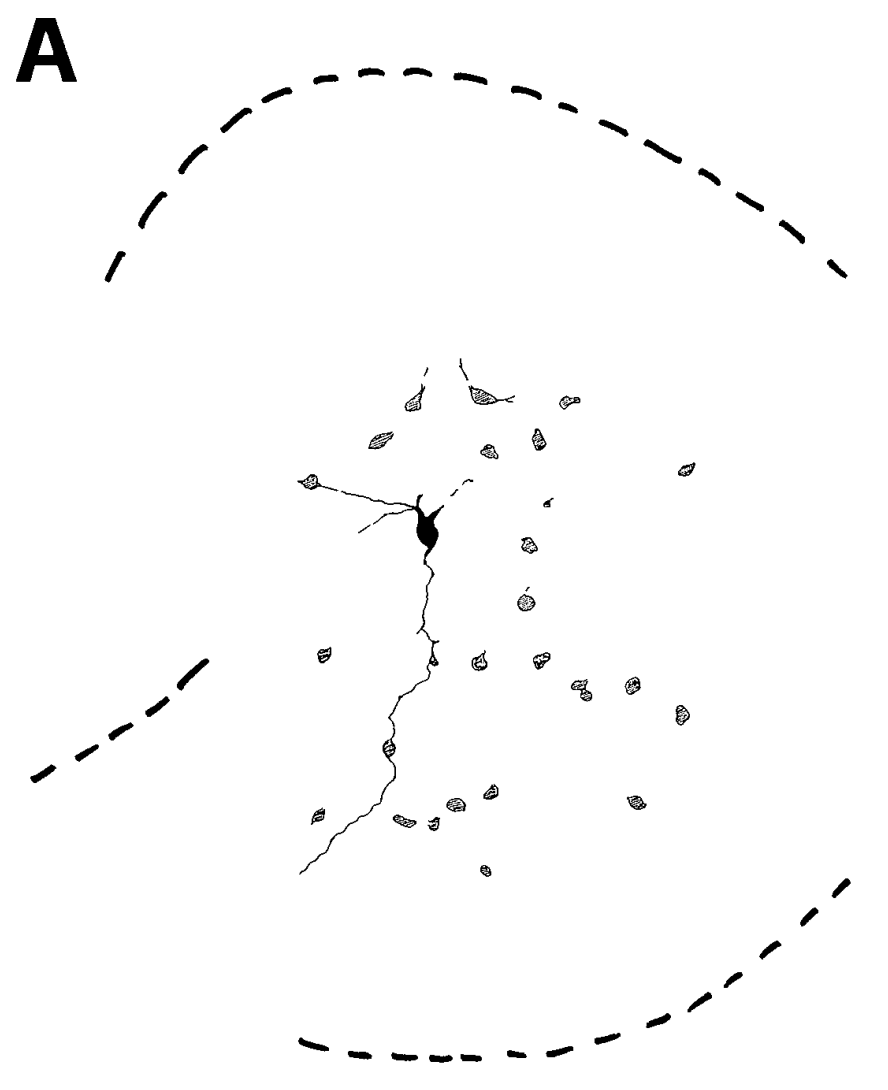

\section{octanol}

B

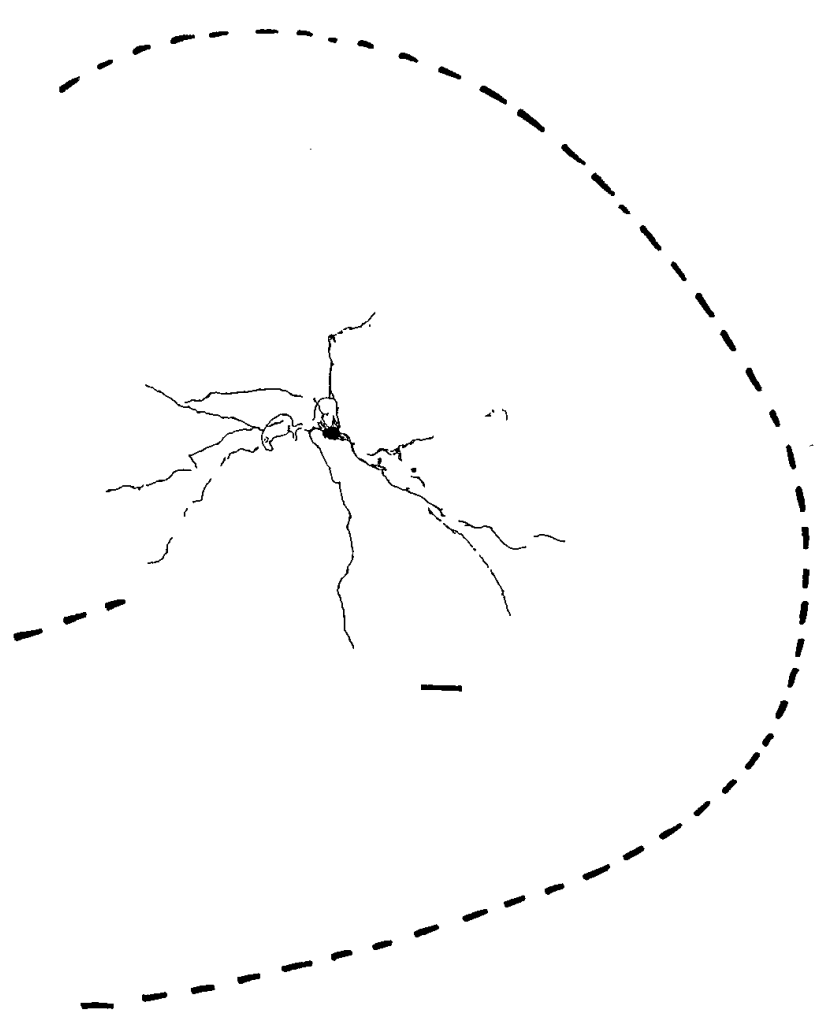

Figure 10. Camera lucida drawings of coupled and uncoupled hilar cells. $A$, The cluster of hilar neurons shown in Figure $4 A$ is compared with the cell of Figure 9 injected in the presence of octanol $(0.5 \mathrm{~mm} ; B)$. Scale bar: $A, 44 \mu \mathrm{m} ; B, 60 \mu \mathrm{m}$.

dye coupling and GFAP-positive cells excluded the involvement of astrocytes in biocytin-stained elements. Moreover, dye-coupled cells often were localized in the middle of the hilus, while, at this age, GFAP-positive glial cells were restricted to the edge of the hilar region (Rickmann et al., 1987). Therefore, the present data strongly suggest that clusters of electrically coupled hilar cells are neuronal elements and constitute the morphological substrate for the generation of GGPs.

The presence of GABAergic cells in the hilus of newborn rats is in agreement with previous reports that showed that they terminate their proliferation by E18-E19 (Lübbers et al., 1985). Moreover, during the first week of postnatal life the number of cells per optical field in the hilus was much larger than in the same region of mature hippocampi (M. Atzori, personal observation). Therefore, this can be explained by the fact that hilar interneurons, densely packed in the hippocampi of newborn rats, migrate to their final position as the hippocampal volume increases. Cell coupling was developmentally regulated, because the number of hilar neurons labeled by a biocytin injection dropped between the first and the second postnatal week, and in agreement with other reports, it was never observed in adult neurons (Buhl et al., 1994; Buckmaster and Schwartzkroin, 1995). However, it is likely that the morphological substrate responsible for gap junctional communication is retained in adult hilar interneurons, because dye coupling was observed in conditions related to an induced excitatory action of GABA (Michelson and Wong, 1994).
In the retina, electrical coupling is decreased by $\mathrm{GABA}_{\mathrm{A}}$ antagonists, suggesting a regulatory role of this neurotransmitter (Piccolino et al., 1982). During development, the shift of GABA from depolarizing to hyperpolarizing having an opposite effect on $\left[\mathrm{Ca}^{2+}\right]_{\mathrm{i}}$ transients (Leinekugel et al., 1995; Obrietan and van den Pol, 1995) might disrupt gap junctional communications.

How might these networks of electrically coupled interneurons lead to the generation of oscillatory events? The present findings demonstrate that this task was accomplished by the inward rectifier cationic current, $I_{\mathrm{h}}$, the role of which in controlling pacemaker activity in other neuronal populations is established (McCormick and Pape, 1990; Maccaferri et al., 1993). $I_{\mathrm{h}}$ resulted from the activation of a nonspecific cationic channel, as shown by the reversal potential value between the $\mathrm{Na}^{+}$and $\mathrm{K}^{+}$equilibrium potentials, and its insensitivity to TTX, 4-AP, TEA, and calcium channel blockers. However, in contrast to other excitable cells (McCormick and Pape, 1990; Di Francesco, 1993; Maccaferri et al., 1993; Dong and Werblin, 1995), in the hilus $I_{\mathrm{h}}$ was very sensitive to external $\mathrm{Cs}^{+}$, being blocked by micromolar concentrations of this ion. The current activation curve in the voltage range between -60 and $-120 \mathrm{mV}$ indicates that maximal activation was achieved at a hyperpolarizing voltage far below the resting membrane potential. Such voltage can be attained during the afterhyperpolarization that follows GGPs. Therefore, $I_{\mathrm{h}}$ seems to be important in determining the rate of GGPs generation by resetting the potential toward the firing level. A similar mecha- 

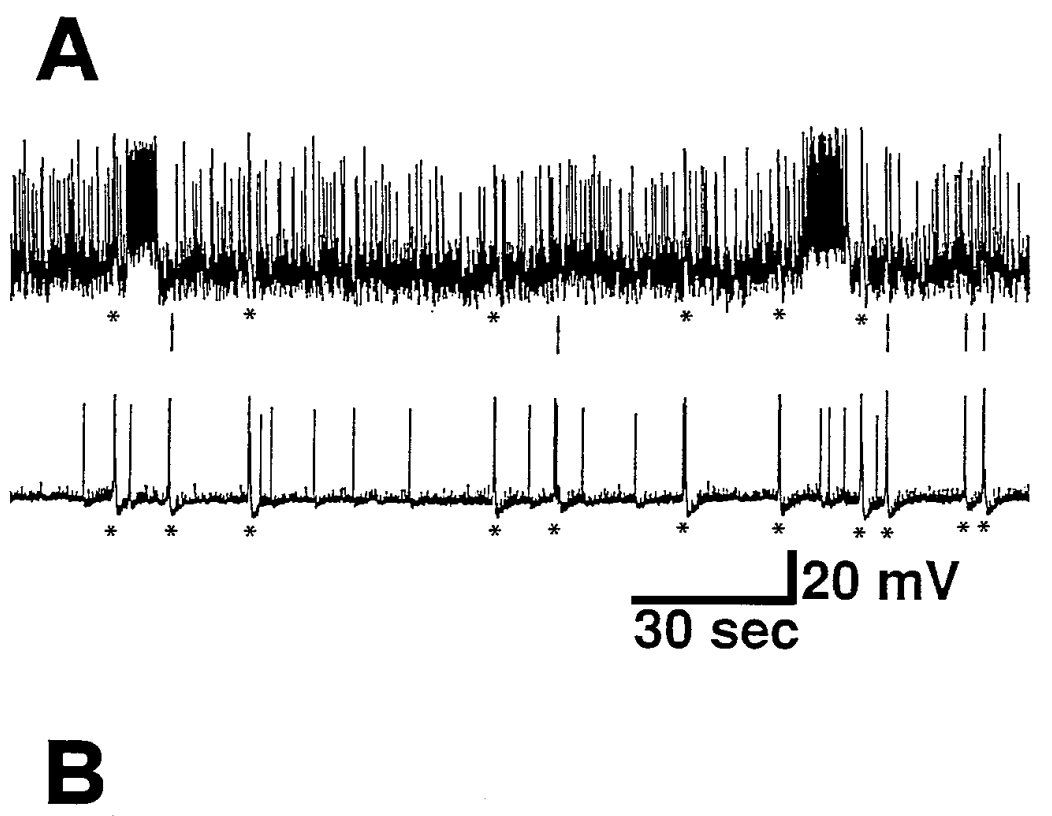

Figure 11. A simplified model of bursting generation and propagation. Paired intracellular recording of a morphologically identified hilar mossy cell (top trace, holding potential $-61 \mathrm{mV}$ ) and a CA3 pyramidal neuron $(-60 \mathrm{mV})$ from a P5 rat. Some GGPs (asterisks) were observed in both cells, but others were not detected in the mossy cell (arrows). Note the long-lasting spontaneous burst of action potential in the mossy cell. Because the mossy cell releases glutamate (Scharfman, 1993), this prolonged depolarization might provide the glutamatergic input to the surrounding coupled interneurons, priming the cascade of amplification as shown in $B$. The first group of coactive interneurons driven by the mossy cell would release GABA and then recruit a larger number of clusters of coupled interneurons. The enhancement in $\left[\mathrm{K}^{+}\right]_{\mathrm{o}}$ evoked by GABA-mediated depolarization (Barolet and Morris, 1991) associated with a poorly developed $\left[\mathrm{K}^{+}\right]_{\mathrm{o}}$ sequestering system (Konietzko and Müller, 1994) may facilitate the spread of the excitation throughout the whole hippocampus. Then the mossy cell is recruited again by GGPs that arose elsewhere.

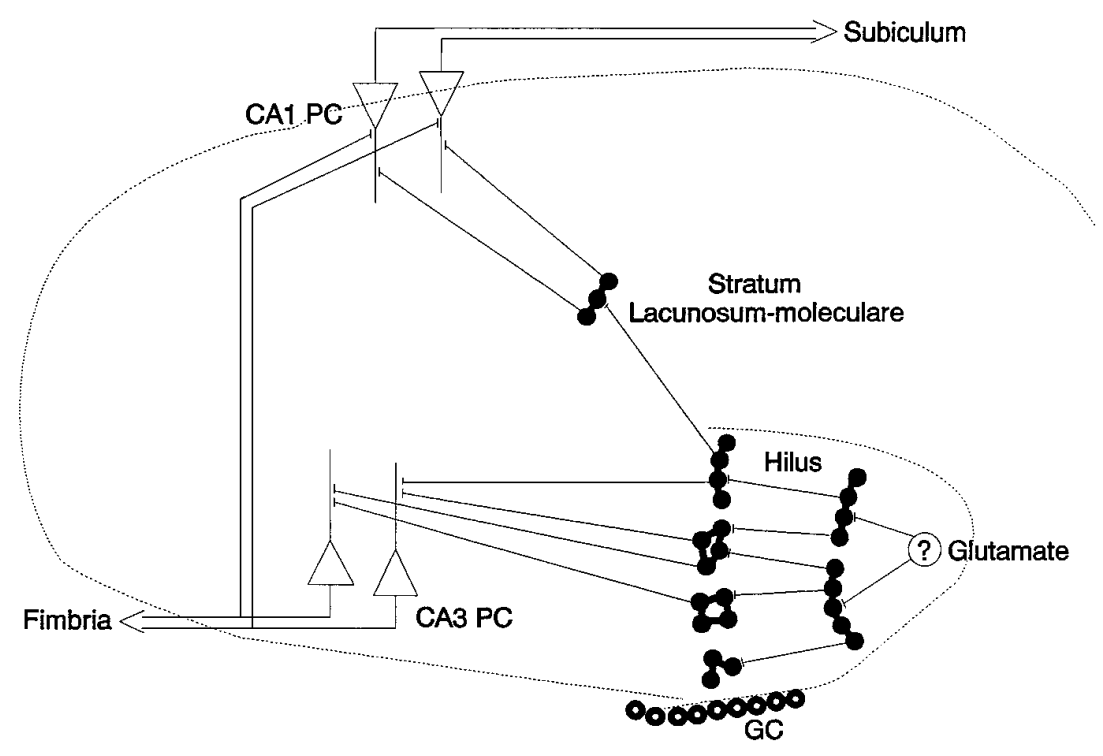

nism was described in heart interneurons of isolated ganglia of the medicinal leech, in which $I_{\mathrm{h}}$ contributes to recovery from inhibition, and, leading to burst initiation, it plays a critical role in the maintenance of the oscillatory activity. In these neurons, blocking $I_{\mathrm{h}}$ with external $\mathrm{Cs}^{+}$disrupts the normal bursting activity. Moreover, $I_{\mathrm{h}}$ has been reported to be sensitive to low concentration of extracellular $\mathrm{Cs}^{+}$(Angstadt and Calabrese, 1989). In our case, the same concentration of extracellular $\mathrm{Cs}^{+}$used to block $I_{\mathrm{h}}$ was able to inhibit GGPs, whereas a lower concentration $(100 \mu \mathrm{M})$ only reduced their frequency.

GGPs were blocked readily by TTX and bicuculline, suggesting that gap junctions, in conjunction with the local release of GABA, are responsible for the synchronized activity of the entire hippocampus. In our case, GABA released from hilar interneurons would depolarize cells, bringing them to fire. Cell depolarization would be followed by an afterhyperpolarization that would activate $I_{\mathrm{h}}$, resetting the potential to the firing level. Although GABAergic neurons (in addition to gap junctions) are important in synchronizing the network, they should be driven by a gluta- matergic input. In fact, in the presence of kynurenic acid no spontaneous GGPs occur (Strata et al., 1995b). Glutamatergic inputs may come from the perforant pathway, hilar mossy cells, or granule cells.

In Figure $11 A$, a pair of recordings has been obtained from cells located in the hilus and in the CA3 region. It was possible to observe a prolonged depolarization in the hilar cell without any counterpart in the CA3 region. The hilar neuron was identified as a mossy cell (shown in Fig. $5 A$ ). This prolonged depolarization would lead to a large release of glutamate that may activate a population of coactive interneurons that, in turn, can recruit other clusters of coupled interneurons, as shown in the scheme of Figure $11 B$.

\section{Physiological significance}

What might be the function of such giant GABAergic activity? Voltage gradients per se, such as those generated by GGPs, might be important for the growth and guidance of axonal fibers not directly related to synaptic specificity (Hinkle et al., 1981; Purves 
and Lichtman, 1985; Jacobson, 1991). On the other hand, GABA itself may act as a molecular signal for the regulation of a variety of developmental processes (Meier et al., 1983). The chronic block of $\mathrm{GABA}_{\mathrm{A}}$ receptors by bicuculline inhibits neuritic growth of hippocampal cells in culture and the development of photoreceptors in the retina (Barbin et al., 1993; Messersmith and Redburn, 1993). Moreover, GABA induces chemokinesis (increased random movement), and therefore it might provide a chemotropic signal to initiate and/or direct GCs migration (Behar et al., 1994). This transmitter can elicit $\left[\mathrm{Ca}^{2+}\right]_{i}$ transient in different systems, important as a developmental signal (Connor et al., 1987; Yuste and Katz, 1991; Reichling et al., 1994; Spitzer, 1994; Gu and Spitzer, 1995).

In kitten striate cortex, blockade of GABA is accompanied by an abnormally low orientation selectivity, associated particularly with a large-sized receptive field (Ramoa et al., 1988). Interfering with this GABA-mediated giant electrical activity might have some important consequence on the development of inhibitory synaptic connections and therefore with the mechanisms responsible for a precise innervation pattern. In the developing hippocampus, interfering with this activity might have important consequences on the selectivity of spatial memory or in temporal lobe epilepsy.

\section{REFERENCES}

Altman J, Bayer SA (1990) Migration and distribution of two populations of hippocampal granule cell precursors during the perinatal and postnatal periods. J Comp Neurol 301:365-381.

Amaral DG (1978) A Golgi study of cell types in the hilar region of the hippocampus in the rat. J Comp Neurol 182:851-914.

Andersen P, Bliss VP, Skrede KK (1971) Lamellar organization of hippocampal excitatory pathways. Exp Brain Res 13:222-238.

Angstadt JD, Calabrese RL (1989) A hyperpolarization-activated inward current in heart interneurons of the medicinal leech. J Neurosci 9:2846-2857.

Barbin G, Pollard H, Gaiarsa JL, Ben Ari Y (1993) Involvement of $\mathrm{GABA}_{\mathrm{A}}$ receptors in the outgrowth of cultured hippocampal neurons. Neurosci Lett 152:150-154.

Barolet AW, Morris ME (1991) Changes in extracellular $\mathrm{K}^{+}$evoked by GABA, THIP, and baclofen in the guinea-pig hippocampal slice. Exp Brain Res 84:591-598.

Behar TN, Schaffner AE, Colton CA, Somogyi R, Olah Z, Lehel C, Barker JL (1994) GABA-induced chemokinesis and NGF-induced chemotaxis of embryonic spinal cord neurons. J Neurosci 14:29-38.

Ben Ari Y, Cherubini E, Corradetti R, Gaiarsa JL (1989) Giant synaptic potentials in immature rat CA3 hippocampal neurons. J Physiol (Lond) 416:303-325.

Boyce LH, Owens DF, Davis MBE, DeVivo DC, Kriegstein AR (1995) Shifts in $\mathrm{GABA}_{\mathrm{A}}$ reversal potential during neocortical development. Soc Neurosci Abstr 22:1508.

Buckmaster PS, Schwartzkroin PA (1995) Physiological and morphological heterogeneity of dentate gyrus-hilus interneurons in the gerbil hippocampus in vivo. Eur J Neurosci 7:1393-1402.

Buhl EH, Halasy K, Somogyi P (1994) Diverse sources of hippocampal unitary inhibitory postsynaptic potentials and the number of synaptic release sites. Nature 368:823-828.

Cherubini E, Gaiarsa JL, Ben Ari Y (1991) GABA: an excitatory transmitter in early postnatal life. Trends Neurosci 14:514-519.

Connor JA, Tseng H-Y, Hockberger PE (1987) Depolarization- and transmitter-induced changes in intracellular $\mathrm{Ca}^{2+}$ of rat cerebellar granule cells in explanted culture. J Neurosci 7:1384-1400.

Di Francesco D (1993) Pacemaker mechanisms in cardiac tissue. Annu Rev Physiol 55:455-472.

Dong CJ, Werblin FS (1995) Inwardly rectifying potassium conductance can accelerate the hyperpolarizing response in retinal horizontal cells. J Neurophysiol 74:2258-2265.

Edwards FA, Konnerth A, Sakmann B, Takahashi TA (1989) A thin-slice preparation for patch-clamp recordings from neurones of the mammalian central nervous system. Pflügers Arch 414:600-612.

Feller MB, Wellis DP, Stellwagen D, Werblin FS, Shatz CJ (1996) Re- quirement for cholinergic synaptic transmission in the propagation of spontaneous retinal waves. Science 272:1182-1187.

Fischer KR, Oakley DM, Wong ROL (1995) Developmental changes in the pattern of correlated spontaneous bursting activity in the ferret retina. Soc Neurosci Abstr 21:1558.

Gaarskjaer FB (1986) The organization and development of the hippocampal mossy fiber system. Brain Res Rev 11:335-357.

Gaiarsa JL, Corradetti R, Cherubini E, Ben Ari Y (1991) Modulation of GABA-mediated synaptic potentials by glutamatergic agonists in neonatal CA3 hippocampal neurons. Eur J Neurosci 3:301-309.

Galli L, Maffei L (1988) Spontaneous impulse activity of rat retinal ganglion cells in prenatal life. Science 242:90-91.

Gu X, Spitzer NC (1995) Distinct aspect of neuronal differentiation encoded by frequency of spontaneous $\mathrm{Ca}^{2+}$ transient. Nature 375:784-787.

Hales TG, Sanderson MJ, Charles AC (1994) GABA has excitatory actions on GnRH-secreting immortalized hypothalamic (GT1-7) neurons. Neuroendocrinology 59:297-308.

Hebb DO (1949) Organization of behaviour. New York: Wiley.

Hinkle L, McCaig CD, Robinson KR (1981) The direction of growth of differentiating neurones and myoblasts from frog embryos in an applied electric field. J Physiol (Lond) 314:121-135.

Horváth G, Acs Z, Mergl Z, Nagy I, Makara GB (1993) Gammaaminobutyric acid-induced elevations of intracellular calcium concentrations in pituitary cells of neonatal rats. Neuroendocrinology 57:1028-1034.

Hosokawa Y, Sciancalepore M, Stratta F, Martina M, Cherubini E (1994) Developmental changes in spontaneous $\mathrm{GABA}_{\mathrm{A}}$-mediated synaptic events in rat hippocampal CA3 neurons. Eur J Neurosci 6:805-813.

Jacobson M (1991) Developmental neurobiology, 3rd Ed, pp 212-214. New York: Plenum.

Kandler K, Katz LC (1995) Neuronal coupling and uncoupling in the developing nervous system. Curr Opin Neurobiol 5:98-105.

Konietzko U, Müller CM (1994) Astrocytic dye coupling in rat hippocampus: topography, developmental onset, and modulation by protein kinase C. Hippocampus 4:297-306.

Leinekugel X, Tseeb V, Ben Ari Y, Bregestovski P (1995) Synaptic GABA activation induces $\mathrm{Ca}^{2+}$ rise in pyramidal cells and interneurons from rat neonatal hippocampal slices. J Physiol (Lond) 487:319-329.

Lübbers K, Wolff JR, Frotscher M (1985) Neurogenesis of GABAergic neurons in the rat dentate gyrus: a combined autoradiographic and immunocytochemical study. Neurosci Lett 62:317-322.

Maccaferri G, Mangoni M, Lazzari A, Di Francesco D (1993) Properties of the hyperpolarization-activated current in rat hippocampal CA1 pyramidal cells. J Neurophysiol 69:2129-2136.

MacLeod N, Johnston A, Swanson G (1994) A novel calcium-dependent oscillation in post-natal mouse lateral geniculate neurones. Soc Neurosci Abstr 20:1686.

Maffei L, Galli-Resta L (1990) Correlation in the discharges of neighboring rat retinal ganglion cells during prenatal life. Proc Natl Acad Sci USA 87:2861-2864.

McCormick DA, Pape HC (1990) Properties of a hyperpolarizationactivated cation current and its role in rhythmic oscillation in thalamic relay neurones. J Physiol (Lond) 431:291-318.

Meier E, Drejer J, Schousboe A (1983) Trophic actions of GABA on the development of physiologically active GABA receptors. In: CNSreceptors from molecular pharmacology to behaviour (Mandel P, DeFeudis FV, eds). New York: Raven.

Meister M, Wong ROL, Baylor DA, Shatz CJ (1991) Synchronous bursts of action potentials in ganglion cells of the developing mammalian retina. Science 252:939-943.

Messersmith EK, Redburn DA (1993) The role of GABA during development of the outer retina in the rabbit. Neurochem Res 18:463-470.

Michelson HB, Wong RKS (1994) Synchronization of inhibitory neurones in the guinea-pig hippocampus in vitro. J Physiol (Lond) 477:35-45.

Obrietan K, van den Pol AN (1995) GABA neurotransmission in the hypothalamus: developmental reversal from $\mathrm{Ca}^{2+}$ elevating to depressing. J Neurosci 15:5065-5077.

Peinado A, Yuste R, Katz LC (1993) Extensive dye coupling between rat neocortical neurons during the period of circuit formation. Neuron 10:103-114.

Penn AA, Wong ROL, Shatz CJ (1994) Neuronal coupling in the developing mammalian retina. J Neurosci 14:3805-3815.

Perez-Velazquez JL, Valiante TA, Carlen PL (1994) Modulation of gap junctional mechanisms during calcium-free induced burst activity: a 
possible role for electrotonic coupling in epileptogenesis. J Neurosci 14:4308-4317.

Piccolino M, Neyton J, Witkowsky P, Gerschenfeld HM (1982) Gamma aminobutyric acid antagonists decrease junctional communication between L-horizontal cells of the retina. Proc Natl Acad Sci USA 79:3671-3675.

Purves D, Lichtman JW (1985) Principles of neural development, pp 124-127. Sunderland, MA: Sinauer.

Ramoa AS, Paradiso MA, Freeman RD (1988) Blockade of intracortical inhibition in kitten striate cortex: effects on receptive field properties and associated loss of ocular dominance plasticity. Exp Brain Res 73:285-296.

Rapisardi SC, Chow KL, Mathers LH (1975) Ontogenesis of receptive field characteristics in the dorsal lateral geniculate nucleus of the rabbit. Exp Brain Res 22:295-305.

Reichling DB, Kyrozis A, Wang J, MacDermott AB (1994) Mechanisms of GABA and glycine depolarization-induced calcium transients in rat dorsal horn neurons. J Physiol (Lond) 476:411-421.

Rickmann M, Amaral DG, Cowan WM (1987) Organization of radial glial cells during the development of the rat dentate gyrus. J Comp Neurol 264:449-479.

Sakatani K, Black JA, Kocsis JD (1992) Transient presence and functional interaction of endogenous GABA and $\mathrm{GABA}_{\mathrm{A}}$ receptors in developing rat optic nerve. Proc R Soc Lond [Biol] 247:155-161.

Scharfman HE (1993) Characteristics of spontaneous and evoked EPSPs recorded from dentate spiny hilar cells in rat hippocampal slices. J Neurophysiol 70:742-757.
Serafini R, Valeyev AY, Barker JL, Poulter MO (1995) Depolarizing GABA-activated $\mathrm{Cl}^{-}$channels in embryonic rat spinal and olfactory bulb cells. J Physiol (Lond) 488:371-386.

Spear PD, Chow KL, Masland RH, Murphy EH (1972) Ontogenesis of receptive field characteristics of superior colliculus neurons in the rabbit. Brain Res 45:67-86.

Spitzer NC (1994) Spontaneous $\mathrm{Ca}^{2+}$ spikes and waves in embryonic neurons: signaling systems for differentiation. Trends Neurosci 17:115-118.

Strata F, Atzori M, Molnar M (1995a) Nitric oxide "paces" giant GABAergic activity in the developing rat hippocampus through a transiently expressed neuronal structure. Soc Neurosci Abstr 21:1297.

Strata F, Sciancalepore M, Cherubini E (1995b) Cyclic AMP-dependent modulation of giant depolarizing potentials by metabotropic glutamate receptors in the rat hippocampus. J Physiol (Lond) 489:115-125.

Wong ROL, Meister M, Shatz CJ (1993) Transient period of correlated bursting activity during development of the mammalian retina. Neuron 11:923-938.

Xie X, Smart TG (1991) A physiological role for endogenous zinc in rat hippocampal synaptic neurotransmission. Nature 349:521-524.

Xie X, Hider RC, Smart TG (1994) Modulation of GABA-mediated synaptic transmission by endogenous zinc in the immature hippocampus in vitro. J Physiol (Lond) 478:75-86.

Yuste R, Katz LC (1991) Control of postsynaptic $\mathrm{Ca}^{2+}$ influx in developing neocortex by excitatory and inhibitory neurotransmitters. Neuron 6:333-344. 